\title{
THRESHOLDS OF GULLY EROSION IN THE COASTAL PLAINS SANDS OF SOUTHEASTERN NIGERIA
}

\section{CHARLES UDOSEN}

(Received 14 May, 2009; Revision Accepted 12 November, 2009)

\begin{abstract}
The concept of geomorphic threshold as applied in gully erosion studies assumes that water erosion occurs when the combined power of the rainfall energy and overland flow exceeds the resistance of surface materials to detachment and entrainment. This line of reasoning presupposes that certain environmental factors that affect runoff generation and erodibility status of soil can be used in estimating thresholds for gully initiation and sustenance. The entire $413 . \mathrm{Km}^{2}$ Ikpa River basin was covered with grids $1 \mathrm{~km}^{2}$ and random number table was used to select $15 \%$ of the target population in the basin. The pair-wise correlation technique was employed to establish the threshold values of vegetation cover, organic matter content, relief, slope gradient, litter cover and bulk density for gully incision and development in the fifth order drainage basin underlain by Coastal Plains Sands in eastern Nigeria. The results of the analyses indicate that the threshold value of vegetation cover was $72.5 \%$, while the thresholds value of depth of litter cover was $3.2 \mathrm{~cm}$. Other threshold values for gully initiation in the catchment area were 1 degree for slope gradient; $2.70 \%$ for organic matter; and 10 metres a.s.I for relief. These threshold values were exceeded in almost all the sampled gully sites. The results of the research have implications for cropping in the study area. The convectional rain-storms that is associated with the beginning of the planting season in April/May cannot be controlled by man. Its effects can be reduced to desirable level by increasing the surface contact cover. Mulching, intercropping and the planting of cover crops can ensure adequate vegetation cover of $>72.5 \%$ on valley -side slopes. Also, crop residue, dry stalks and stovers should be used to encourage the build-up of organic matter above the critical level of $2.70 \%$ during the planting season.
\end{abstract}

KEYWORDS: Gully erosion, threshold, Ikpa river, coastal plains, morphometry, intrinsic factors

\section{INTRODUCTION}

Gully erosion has been defined as 'any erosion channel so wide that it cannot be crossed by a wheeled vehicle or obliterated by farm implements' (Udosen, 2008). In the loose, friable Coastal Plains Sands, the problem of erosion has assumed an alarming proportion. It is a relentless destroyer of farmlands, buildings, roads and other infrastructures in the various sedimentary formations of the country

A question which arises is what are the critical values of environmental factors responsible for gully initiation and sustenance? Erosion factors are simply the critical condition or a combination of factors at which soil erosion is initiated. It may be induced when an intrinsic or extrinsic threshold is crossed, as in the modification in vegetation cover or drastic changes in climatic conditions. Hence, in a given landscape, whether a gully is initiated or not depends on the nature of the earth material, rainfall characteristics, the extent of the vegetation cover and the slope length and steepness, all of which combine to determine, the resistance to the tractive force.

Erosion factors vary from one environment to another, depending on the complex combinations of the environmental factors that determine the volume and intensity of runoff on hill and valley slopes(Graf, 1979; Ofomata,1967; Schumm,1973,1979; and Ebisemiju,1989b\}. The present study attempts to identify the values of the parameters for gully initiation and development in the Coastal Plains

Charles Udosen, Department of Geography, University of Uyo, Uyo, Akwa Ibom State 